\title{
ANALYSIS OF FOREST FIRE BEHAVIOUR BY ADVANCED COMPUTER FIRE SIMULATORS
}

Computer modelling of dangerous phenomena related to fire in forest or in wildland-urban interface is an important tool to support emergency planning for such complicated events. In this paper, the use of FARSITE (Fire ARea SImulaTor), adapted for real conditions in Slovak Paradise National Park (Slovakia), and WFDS (Wildland-urban interface Fire Dynamics Simulator) for simulation of forest fires and fires in wildland-urban interface is demonstrated. Computer reconstruction of an especially tragic destructive forest fire happened in 2000 as well as simple examples of automobile fire in wildland-urban interface are illustrated.

Keywords: computer fire simulation, forest fire behaviour, FARSITE, FDS, WFDS

\section{Introduction}

Unwanted forest fires and fires in wildland-urban interface (WUI) are known as highly dangerous destructive phenomena threatening people's lives and causing great vegetation and property damages. Forest fires devastate badly natural scenery, eco-systems and environment of the landscape afflicted by fire. Advances in information technologies stimulate the development of computer systems capable to simulate fire spread and its spatial and temporal behaviour to support fire management decisions. Such systems can be used for fire prevention and planning purposes, for education and training, but also for operational purposes facing active fires. Computer simulation can also be used as a means to analyse the effectiveness of suppression strategies and tactics taking into account existing infrastructure and specific regional conditions. It can be useful also for past fire events reconstruction to better understand the circumstances that lead to fatal tragic incidents and great losses of values and property during the fires [16, 27, 37 38, 44]. Several advanced forest fire simulators (e.g. the FARSITE, WILDFIRE, FIRESTATION, FIREMAP, WFDS, FIRETEC, FIRESTAR, CAFME systems) have been developed for such purposes. Mostly they are based on empirical and semi-empirical fire spread models suitable for simulation of more extensive forest fires being applicable also for operational purposes and realized on currently available computer equipment. However, some of them utilize physical models which allow to capture more of complexity of burning process in smaller spaces with higher spatial data resolution. Since physical models are based on numerical solving complex differential equations, they require specialized high-performance computational environment operating in parallel [26].

In this paper, we demonstrate the use of two advanced simulators, the FARSITE (Fire ARrea SImulaTor) and WFDS (Wild- land-urban interface Fire Dynamics Simulator) systems, which are representatives of both classes of simulation systems. FARSITE is illustrated by results of the reconstruction of one especially tragic forest fire which happened in 2000 in the Slovak Paradise National Park (Slovakia). During the fire, dozens of hectares of unique forests in Three Hills Natural Landscape Reservation were burnt off and six people died. We adapted FARSITE for real fire conditions and studied reasons which made the fire so tragic and destructive. For such purposes, we made detailed analysis of the region to detect dangerous tendencies of fire propagation and risky places in the territory. The mentioned tragic consequences of the fire in Slovak Paradise in 2000 stimulated the forest fire research in Slovakia. Research focusses both on new as well as on existing means and know-how applicable for fire prevention, planning and fire-fighting in Slovak forests. Several national research institutions began a joint research project covering also the study of computer fire simulation as a means for fire management decision support.

The use of WFDS is illustrated studying the interaction between automobile fire and vegetation fire sometimes occurred in WUI. Since Slovakia belongs to countries with high forest cover (about $45 \%$ of total area; $23 \%$ from that are national parks and other protected areas) and to countries with highest automobile production per capita in Europe, the number of automobiles and their concentration grow rapidly and automobile fires have become a significant part of registered fires in Slovakia [4, 6, 28, 29, 31]. Moreover, at eastern Slovak border (which is also the EU border, the great part of which is covered by wild forest), terrain automobile patrols are inevitable for border protection, which makes readiness for possible failures and fires particularly significant. From these reasons, national consortium of research and fire-fighters teams was established to solve practical problems of fire safety, including automobile fire safety and particularly automobile-in-WUI-fire safety.

\footnotetext{
* Jan Glasa, Peter Weisenpacher, Ladislav Halada,

Institute of Informatics, Slovak Academy of Sciences, Bratislava, Slovakia, E-mail: jan.glasa@savba.sk
} 
For these purposes, in 2009 and 2010, a series of full-scale automobile fire experiments was carried out in testing facilities of Fire Protection College of the Ministry of Interior of Slovak Republic in Povazsky Chlmec (Slovakia) and in two experimental tunnels of Scientific Research Coal Institute in Stramberk and in Ostrava (Czech Republic) [17, 28, 32, 34, 43] to gather data required for subsequent computer simulation of various possible automobile fire scenarios [17, 41-43]. The primary objective of these experiments was to measure gas and surface temperatures to gather data for validation of computer simulations of the tested automobile fire scenarios and to obtain better knowledge about ignition and burning of a single automobile and about the fire spread from one vehicle onto other vehicles, or onto other structures or vegetation.

\section{FARSITE simulation for past fire event reconstruction}

FARSITE $[5,30]$ belongs to the best forest fire simulators based on semi-empirical fire spread models. We studied mathematical foundations of methods implemented in FARSITE and in other selected simulators $[8-12,15,39,40]$ to make possible the proper use of FARSITE and its adaptation for intended computer fire simulation in Slovak conditions. Its applicability for Central European forests was assumed because it has already been tested in several countries of Mediterranean and Western Europe (see e.g. $[2,3,18,19])$. Since the standard NFFL fuel models [1] were originally developed for conditions of top fire season outside Europe, new original fuel models had to be defined to fit specific vegetation conditions in Slovak Paradise (see Figs. 1-2). In order to achieve reliable computer fire reconstruction, real input data describing topography, vegetation cover and meteorological situation were gathered $[21,33,35,36]$ and FARSITE was calibrated to real fire conditions. An original fuel model representing real vegetation at the site was defined (see Table 1) validating the fuel parameters by field investigations and laboratory evaluation of collected vegetation samples [21,35].

To answer two questions, why the burning area in first hours had such a significantly elongated oval shape and why the people were entrapped by the fire, we investigated various fire scenarios and made a big number of particular FARSITE simulations to better understand specific fire behaviour in given region. The simulation results confirmed increasing fire danger just in the vicinity of the place of human tragedy [7, 13, 14, 16] (see Fig. 3 and Tables 2-3). FARSITE showed its great potential for fire danger analysis and computer reconstruction of past fire events, as well as for fire prevention and planning purposes.

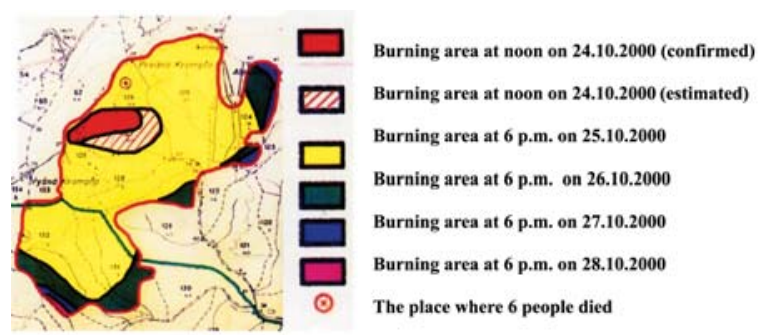

Fig. 1 Fragment from the fire documentation [20]

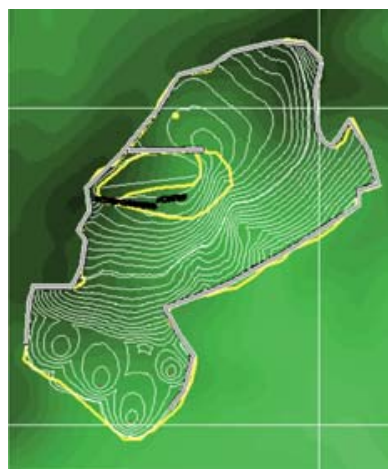

(i)

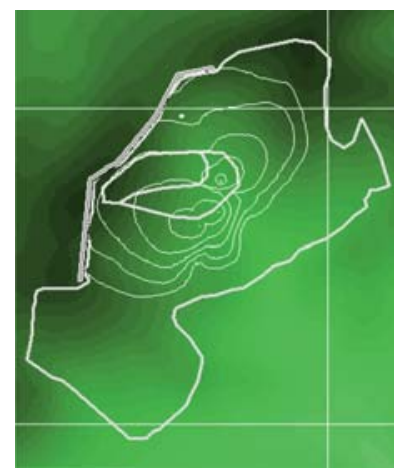

(ii)
Fig. 3 (i) First two days simulation (1-hour perimeters plotted); (ii) simulation initiated at three points (1.5-hour perimeters plotted)
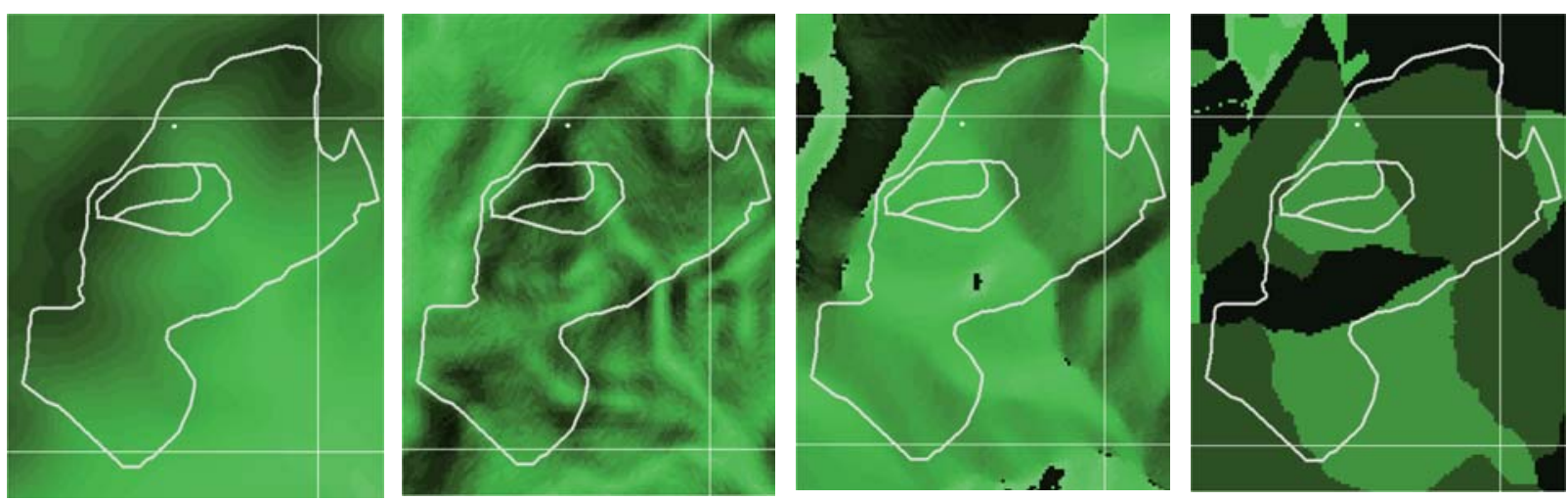

Fig. 2 Spatial data layers (elevation, slope, aspect, canopy cover) for the fire simulation 
Fuel model parameters where DFL is $1 \mathrm{~h}, 10 \mathrm{~h}$ and $100 \mathrm{~h}$ dead fuel loading [t/ha], LHFL is live herbaceous fuel loading [t/ha],

Table 1 LWFL is live woody fuel loading [t/ha], DFSTR is $1 \mathrm{~h}$ dead fuel surface to volume ratio $[1 / \mathrm{cm}]$, LHFSVR is live herbaceous fuel surface to volume ratio [1/cm], LWFSVR is live woody fuel surface to volume ratio $[1 / \mathrm{cm}]$, FBD is fuel bed depth $[\mathrm{m}]$, DFEM is dead fuel extinction moisture [\%], HCDF is heat content of dead fuels $[\mathrm{kJ} / \mathrm{kg}]$, and HCLF is heat content of live fuels $[\mathrm{kJ} / \mathrm{kg}]$

\begin{tabular}{|c|c|c|c|c|c|c|c|c|c|c|c|}
\hline $\begin{array}{c}\text { DFL } \\
1 \mathrm{~h}\end{array}$ & $\begin{array}{c}\text { DFL } \\
10 \mathrm{~h}\end{array}$ & $\begin{array}{c}\text { DFL } \\
100 \mathrm{~h}\end{array}$ & LHFL & LWFL & $\begin{array}{c}\text { FSVR } \\
1 \mathrm{~h}\end{array}$ & $\begin{array}{c}\text { LHF } \\
\text { SVR }\end{array}$ & $\begin{array}{c}\text { LWF } \\
\text { SVR }\end{array}$ & FBD & DFEM & HCDF & HCLF \\
\hline 5.842 & 3.499 & 0.339 & 0.473 & 1.57 & 77.8 & 49.0 & 49.0 & 32 & 27 & 18600 & 18600 \\
\hline
\end{tabular}

Fire behaviour parameters where ST is simulation time [month/day time], RoS is rate of spread $[\mathrm{m} / \mathrm{min}]$ and $\mathrm{FL}$ is flame length $[\mathrm{m}]$

\begin{tabular}{|cc|c|c|}
\hline \multicolumn{2}{|c|}{ ST } & RoS & FL \\
\hline $10 / 24$ & $10: 00$ & 0.6 & 0.7 \\
\hline $10 / 24$ & $11: 00$ & 0.1 & 0.3 \\
\hline $10 / 24$ & $12: 00$ & 0.3 & 0.5 \\
\hline $10 / 24$ & $13: 00$ & 0.3 & 0.5 \\
\hline $10 / 24$ & $14: 00$ & 0.4 & 0.5 \\
\hline $10 / 24$ & $15: 00$ & 1.7 & 1.0 \\
\hline
\end{tabular}

Fire size where ST is simulation time [month/day time], $\mathrm{PL}$ is perimeter length $[\mathrm{km}]$ and BA is burned area [ha]

\begin{tabular}{|c|c|c|}
\hline ST & PL & BA \\
\hline $10 / 24 \quad 9: 00$ & 0.71 & 0.00 \\
\hline $10 / 24 \quad 10: 00$ & 0.94 & 4.11 \\
\hline $10 / 24 \quad 11: 00$ & 1.32 & 5.44 \\
\hline $10 / 24 \quad 12: 00$ & 1.73 & 6.44 \\
\hline $10 / 24 \quad 13: 00$ & 2.24 & 8.22 \\
\hline $10 / 24 \quad 14: 00$ & 2.72 & 11.59 \\
\hline $10 / 24 \quad 15: 00$ & 3.24 & 16.51 \\
\hline $10 / 24 \quad 18: 00$ & 3.87 & 26.74 \\
\hline $10 / 24 \quad 21: 00$ & 4.27 & 34.09 \\
\hline $10 / 25 \quad 21: 00$ & 6.31 & 69.99 \\
\hline
\end{tabular}

\section{Table 2 3. WFDS simulation of automobile fire in WUI}

Computer simulation of automobile fires in WUI belongs to the most complex simulation problems at all. However, in recent years several advanced simulation programs capable to model some features of the problem have been developed. WFDS [22-24] was developed as an extension of the well-known Fire Dynamics Simulator [25] which is meant to simulate fires in human structures. The WFDS system allows to include vegetation fuel into fire simulation and to utilize increasing computational power of current computer systems even for more complex fire scenarios. In this part, two typical fire scenarios which occur during automobile fires in WUI are illustrated: the first scenario represents the spread of fire ignited in automobile engine compartment onto the crown of a near standing tree and the second one simulates the spread of shrub fire onto a near standing automobile. Firstly, we made FDS simulation of automobile fire ignited in engine compartment which provided a realistic description of typical automobile fire scenario [41, 42]. The simulation reproduced the main features of the fire spread correctly and provided realistic fire spread description in the vicinity of the vehicle engine compartment. Next, we incorporated the automobile fire behaviour into WFDS simulation using the heat release rate (HRR) behaviour and observed material parameters of bodywork varnish as input data for both fire scenarios.

The first fire scenario configuration is shown in Fig. 4i, where the automobile bodywork is modelled explicitly and the automobile fire behaviour is prescribed by the HRR values obtained from the FDS simulation. The fire above the bodywork interstices is represented by six stripes of prescribed HRR located bellow the

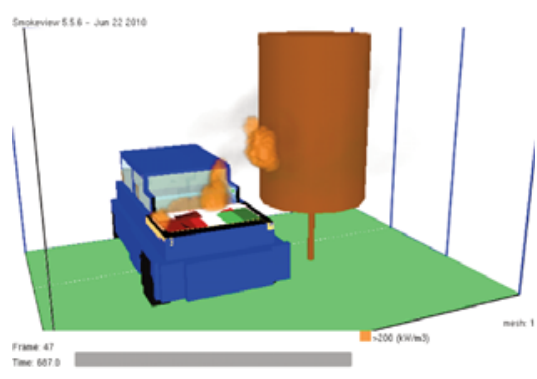

(i)

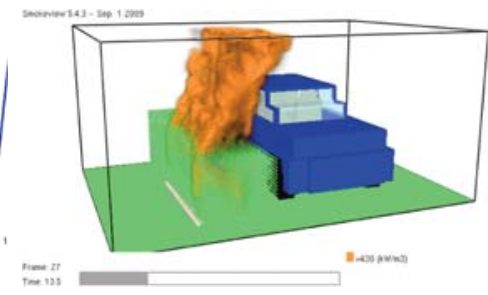

(ii)

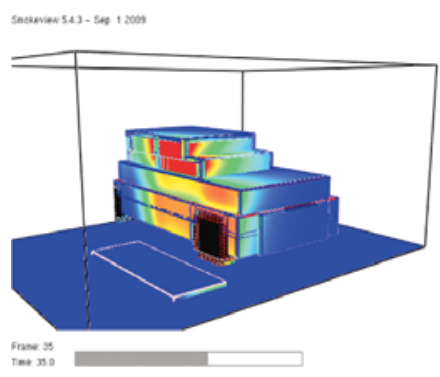

(iii)

Fig. 4 (i) Automobile fire spread onto a tree; (ii) shrub fire spread onto an automobile and (iii) impact of shrub fire on automobile in the distance $10 \mathrm{~cm}$ and wind speed $2 \mathrm{~m} \cdot \mathrm{s}^{-1}$ 
front window corresponding to the FDS simulation. In order to simulate the fire spread on the lid, the varnish fire HRR is prescribed distinctively for the particular parts of the lid which ignited one after another. The used tree crown parameters correspond to tree with the moisture content $20 \%$, surface to volume ratio $4000 \mathrm{~m}^{-1}$, fuel element density $520 \mathrm{~kg} \cdot \mathrm{m}^{-3}$ and crown bulk density $1.5 \mathrm{~kg} \cdot \mathrm{m}^{-3}$. The crown of cylindrical shape has the following parameters: the crown height $3.4 \mathrm{~m}$, crown base height $1 \mathrm{~m}$ and crown base width $1.6 \mathrm{~m}$. Initial temperature is set to $35^{\circ} \mathrm{C}$. The whole calculation domain $(600 \times 450 \times 360 \mathrm{~cm}$ with the resolution $5 \mathrm{~cm}$ and $10 \mathrm{~cm})$ was decomposed into three meshes $(120 \times 30 \times 72$ cells, $60 \times$ $15 \times 36$ cells and $60 \times 15 \times 36$ cells); the finer resolution was used in the region including the lid and parts in the wind speed direction where the main part of fire transfer was expected. Simulation of $100 \mathrm{~s}$ of fire required 7-8 hours of CPU time at Intel Q9550, $2.83 \mathrm{GHz}$ CPU. The influence of wind speed and the distance between automobile and vegetation on the tree crown ignition was investigated (see Table 4).

Time of crown ignition for different values

Table 4 of wind speed and tree distance

\begin{tabular}{|l|c|c|c|c|c|}
\hline & $0 \mathrm{~cm}$ & $20 \mathrm{~cm}$ & $40 \mathrm{~cm}$ & $70 \mathrm{~cm}$ & $100 \mathrm{~cm}$ \\
\hline $0 \mathrm{~m} . \mathrm{s}^{-1}$ & $735 \mathrm{~s}$ & no ignition & no ignition & no ignition & no ignition \\
\hline $1 \mathrm{~m} \cdot \mathrm{s}^{-1}$ & $673 \mathrm{~s}$ & $736 \mathrm{~s}$ & $842 \mathrm{~s}$ & no ignition & no ignition \\
\hline $2 \mathrm{~m} . \mathrm{s}^{-1}$ & $659 \mathrm{~s}$ & $685 \mathrm{~s}$ & $726 \mathrm{~s}$ & $825 \mathrm{~s}$ & no ignition \\
\hline
\end{tabular}

The second fire scenario configuration is shown in Fig. 4ii, where the shrub is represented by a rectangular block consisting of four particle classes (see Table 5). We studied the influence of wind speed and the distance between vehicle and shrub on the automobile ignition. The computational domain dimensions are $500 \times 250 \mathrm{~cm}$ in $\mathrm{y}$ - and z-coordinates varying from 500 to $600 \mathrm{~cm}$ in $\mathrm{x}$-coordinate (in dependence on the distance) with the resolution $5 \mathrm{~cm}$. Simulation of $60 \mathrm{~s}$ fire required 18-35 hours of CPU time at Intel Q9550, $2.83 \mathrm{GHz}$ CPU. Table 6 shows the impact of the shrub fire onto the automobile (see also Fig. 4iii).

\section{Conclusion}

Computer reconstruction of past forest fire events and the use of advanced fire spread simulators can help fire management as means of strategic fire-fighting and planning decision support.
Material properties of shrub fuel classes where SFC

Table 5 is shrub fuel class, SVR is surface to volume ratio $[1 / \mathrm{m}]$, $\mathrm{VM}$ is vegetation moisture [\%], VD is vegetation density $\left[\mathrm{kg} / \mathrm{m}^{3}\right]$ and VBD is vegetation bulk density $\left[\mathrm{kg} / \mathrm{m}^{3}\right]$

\begin{tabular}{|c|c|c|c|c|}
\hline SFC & SVR & VM & VD & VBD \\
\hline 1 & 4000 & 50 & 520 & 1.5 \\
\hline 2 & 2667 & 50 & 520 & 0.25 \\
\hline 3 & 889 & 50 & 520 & 0.25 \\
\hline 4 & 500 & 50 & 520 & 0.25 \\
\hline
\end{tabular}

The FARSITE reconstruction of the fire in Slovak Paradise National Park, during which six people were entrapped by fire, demonstrates that FARSITE, adapted for specific Slovak conditions, is able to reproduce fundamental fire behaviour features. Fire propagation analysis indicates especially dangerous fire spread tendencies and increasing fire danger just in the vicinity of the place where the people died. The simulation results also helped exclude some earlier assumptions related to the way of the fire origin and showed several probable ways how the fire could start. Since quickness and efficiency of fire suppression and fire management answer to fire event is very important, such advanced simulation tool, operating almost in real-time on commonly available computers, allows the fire management to test various aerial and/or ground attack tactics and strategic fire-fighting decisions.

The use of advanced fire simulation tools to study automobile fires in forest (or in WUI), validated by full-scale automobile fire experiments carried out, is a challenging not yet solved problem. In this paper, two WFDS simulations of automobile fires in WUI are described. The knowledge obtained during the series of fire experiments conducted in Slovakia and in Czech Republic in 2009 and 2010, and the subsequent FDS simulation of various automobile fire scenarios are used to study the spread of automobile fire onto near standing vegetation and vice versa. The first scenario represents the spread of automobile fire onto the crown of near standing tree. The FDS simulation allows to simulate the fire behaviour in the vicinity of the automobile in detail with high resolution. Then, the simulation results are incorporated into WFDS simulation, performed on the larger scale with lower resolution, in order to study the impact of automobile fire on near standing tree. In the second fire scenario, WFDS was used for studying the spread of shrub fire onto near standing automobile. Ignition of combustible automobile components is a very complicated and complex process which will require more detailed research. However, it was demon-

Automobile components ignited by shrub fire for different values of wind speed and shrub distance

Table 6

\begin{tabular}{|c|c|c|c|c|c|c|c|}
\hline & $10 \mathrm{~cm}$ & $25 \mathrm{~cm}$ & $50 \mathrm{~cm}$ & $75 \mathrm{~cm}$ & $100 \mathrm{~cm}$ & $125 \mathrm{~cm}$ & $150 \mathrm{~cm}$ \\
\hline $0 \mathrm{~m} \cdot \mathrm{s}^{-1}$ & tyre & tyre & tyre & tyre & no ignition & no ignition & no ignition \\
\hline $1 \mathrm{~m} \cdot \mathrm{s}^{-1}$ & tyre & tyre & tyre & tyre & no ignition & no ignition & no ignition \\
\hline $2 \mathrm{~m} \cdot \mathrm{s}^{-1}$ & tyre, varnish & tyre & tyre & tyre & no ignition & no ignition & no ignition \\
\hline $3 \mathrm{~m} . \mathrm{s}^{-1}$ & tyre, varnish & tyre & tyre & tyre & tyre & tyre & no ignition \\
\hline
\end{tabular}


strated that the used approach allows to solve practical problems of great importance for fire safety purposes. The simulation can describe the main fire spread tendencies as well as quantitative fire characteristics providing useful information for the design of automobiles and human structures, the fire safety arrangements and regulations, as well as for the development of fire-fighting strategies in specific conditions. Since the computational requirements of such simulations are significant, proper parallel implementation of typical fire scenarios on clusters of computers is a challenging problem.

\section{Acknowledgments}

The authors would like to thank to plk. Ing. Jaroslav FLACHBART, PhD., the director of Fire Protection College of the Ministry of Interior of the Slovak Republic in Zilina, for his kind help during the fire experiments. This paper was partially supported by Slovak Scientific Research Agencies APVV (project APVV-053207) and VEGA (project VEGA 2/0216/10).

\section{References}

[1] ANDERSON, H. E.. Aids to Determining Fuel Models for Estimating Fire Behaviour, USDA For. Serv. Gen. Tech. Rep. INT-122, 1982.

[2] ARCA, B., DUCE, P., PELliZARO, G., LACONI, M., SALIS, M., SPANO, D.: Evaluation of FARSITE Simulator in Mediterranean Shrubland, Forest Ecology and Management, Vol. 234S, pp. S110, 2006.

[3] DUGUY, B., AllOZA, J. A., RODER, A., VALlEJO, R., PASTOR, F.: Modelling the Effects of Landscape Fuel Treatments on Fire Growth and Behaviour in a Mediterranean landscape (Eastern Spain), Int. J. of Wildland Fire, Vol. 16, pp. 619-632, 2007.

[4] FAITH, P.: Passenger Road Transport Trends in the Slovak Republic, Communications - Scientific Letters of the University of Zilina, No. 3, pp. 33-39, 2008.

[5] FINNEY, M. A.: FARSITE: Fire Area Simulator - Model, Development and Evaluation, Research Paper RMRS-RP-4, USDA Forest Service, 1998.

[6] GALLA, S.: Fire Intervention of Fire and Rescue Brigade (in Slovak), Proc. of the Workshop on Fire Risk and Damage Event Liquidation, Bratislava, 2010.

[7] GLASA, J.: Computer Simulation and Predicting Dangerous Forest Fire Behaviour, Int. J. on Mathematics and Computers in Simulation, Vol. 3, No. 2, pp. 65-72, 2009.

[8] GLASA, J., HALADA, L.: Application of Envelope Theory for 2D Fire Front Evolution, Forest Ecology and Management, Vol. 234S, pp. 129, 2006.

[9] GLASA, J., HALADA, L.: Envelope Theory and its Application for a Forest Fire Front Evolution, J. of Applied Mathematics, Statistics and Informatics, Vol. 3, No. 1, pp. 27-37, 2007.

[10] GLASA, J., HALADA, L.: On Elliptical Model for Forest Fire Spread Model Modelling and Simulation, Mathematics and Computers in Simulation, Vol. 78, No. 1, pp. 76-88, 2008.

[11] GLASA, J., HALADA, L.: On Mathematical Foundations of Elliptical Forest Fire Spread Model, Chapter 12, pp. 315-333. In: Forest Fires: Detection, Suppression and Prevention (E. Gomez, K. Alvarez, eds.), Nova Science Publishers, Inc., N.Y., 350 p, 2009.

[12] GLASA, J., HALADA, L.: A Generalization of Elliptical Fire Spread Model, Proc. of the Int. Conf. on Forest Fire Research, Coimbra, 2010.

[13] GLASA, J., WEISENPACHER, P., HALADA, L.: Analysis of Forest Fire Behaviour by Computer Simulation (in Slovak), Transactions of the VSB-Technical University Ostrava, Safety Engineering Series, Vol. 3, Iss. 1, pp. 23-33, 2008.

[14] GLASA, J., WEISENPACHER, P., HALADA, L.: Tragic Forest Fire in Slovak Paradise: Ten Years After, Proc. of the Int. Conf. on Forest Fire Research, Coimbra, 2010.

[15] HALADA, L., WEISENPACHER, P.: Principles of Forest Fire Spread Models and their Simulation, J. of Applied Mathematics, Statistics and Informatics, Vol. 1, No. 1, 2005, pp. 3-13, 2005.

[16] HALADA, L., WEISENPACHER, P., GLASA, J.: Reconstruction of the Forest Fire Propagation Case when People were Entraped by Fire, Forest Ecology and Management, Vol. 234S, pp. 127, 2006.

[17] HALADA, L., WEISENPACHER, P., GLASA, J. Possible Use of Computer Fire Simulation for Automobile Fire Safety Purposes, Proc. of Int. Conf. on Fire Safety and Rescue Services, Zilina, pp. 68-77, 2010.

[18] HARVEY, S., RUEGSEGGER, M., ALLGOWER, B.: Fuel Models for Switzerland (Swiss National Park), Final Report of EU RP Minerve 2, No. EV5VCT-0570, Zurich, 1997.

[19] HILlE, M., GOLDAMMER, J. G.: Dispatching and Modeling of Fires in Central European Pine Stands: New Research and Development Approaches in Germany, Proc. of the Workshop at Agronomic Inst. of Chania, pp. 59-74, 2001.

[20] JUHAS, F.: Forest Fire in the Slovak Paradise National Park: October 2000 (in Slovak), Fire Service, Spisska Nova Ves, 2000.

[21] MAJlingOVA, A., VIDA, T., TUCEK, J.: Fuel Models Specification for Fire Modelling and Simulation Purposes Using Existing Information about Forests, Proc. of the Int. Conf. on Fire Safety, Novi Sad, pp. 444-455, 2006.

[22] MELL, W. E., MANZELLO, S. L., MARANGHIDES, A.: Numerical Modelling of Fire Spread through Trees and Shrubs, Forest Ecology and Management, Vol. 234S, pp. 82, 2006. 
[23] MELL, W. E., JENKINS, M. A., GOULD, J., CHENEY, P.: A Physics-based Approach to Modelling Grassland Fires, Int. J. of Wildland Fire, Vol. 16, No. 1, pp. 1-22, 2007.

[24] MELL, W., MARANGHIDES, A., McDERMOTT, R., MANZELLO, S. L.: Numerical Simulation and Experiments of Burning Douglas Fir Trees, Combustion and Flame, Vol. 156, pp. 2023-2041, 2009.

[25] McGRATTAN, K. B., HOSTIKKA, S., FLOYD, J. E., BAUM, H. R., REHM, R. G.: Fire Dynamics Simulator, Technical Reference Guide 5th Edition, National Institute of Standards and Technology Special Publication 1018-5, Gaithersburg, Maryland, 2007.

[26] OLDEHOEFT, R.: Taming Complexity in High-performance Computing, Mathematics and Computers in Simulation, Vol. 54, pp. 314-357, 2000

[27] OLIVEIRA, R. F., ROSSA, C. G., RIBEIRO, L. M., VIEGAS, D. X.: A Study on Forest Fires in the State of Victoria (Australia) in February 2009, Proc. of the Int. Conf. on Forest Fire Research, Coimbra, 2010.

[28] POLEDNAK, P.: Experimental Verification of Automobile Fires (in Slovak), Proc. of the Int. Conf. on Fire Safety and Rescue Services, Zilina, pp. 248-255, 2010.

[29] PONCE, I., POLEDNAK, P.: Automobile Fires (in Slovak). Proc. of the Int. Conf. on Fire Safety and Rescue Services, Zilina, pp. 269-274, 2006.

[30] SELI, R. C., FIEDLER, J. R., CALKIN, D. E.: Coupling Fire Behaviour Models with other Decision Support Tools, Proc. of the Int. Conf. on Forest Fire Research, Coimbra, 2010.

[31] SIMAK, L.: Increasing the Security Level in the Slovak Republic, Communications - Scientific Letters of the University of Zilina, Vol. 2, pp. 67-71, 2008

[32] SIMONOVA, M.: Automobile Fires in Closed Spaces (in Slovak), Proc. of the Int. Conf. on Fire Safety and Rescue Services, Zilina, pp. 284-291, 2010.

[33] SKVARENINA, J., MINDAS, J., HOLECY, J., TUCEK, J.: An Analysis of the Meteorological Conditions During Two Largest Forest Fire Events in the Slovak Paradise National Park, J. of Meteorology, Vol. 7, pp. 167-171, 2004.

[34] SVETLIK, J.: Fire in Automobile Engine Compartment (in Slovak), Proc. of the Int. Conf. on Fire Safety and Rescue Services, Zilina, pp. 272-277, 2010.

[35] TUCEK, J., MAJLINGOVA, A.: Forest Fires in Slovak Paradise National Park: Applications of Geoinformatics (in Slovak), TU at Zvolen, 172 p., 2007.

[36] TUCEK, J., SCHMIDT, M., CELER, S.: Classification of Vegetal Cover in High Mountain Conditions from High-density RSA Data Using Aprior Knowledge, Acta Facultatis Forestalis, Vol. XLVII, pp. 91-102, 2005.

[37] VIEGAS, D. X., CABALlERO, D.: The Accident of Guadalajara (Spain) 2005. In: Recent Forest Fire Related Accidents in Europe (VIEGAS, D. X., ed.), EC JRC, Luxembourg, pp. 3-17, 2009.

[38] VIEGAS, D. X., ROSSA, C., CABALlERO, D., PITA, L. P. C., PALHEIRO, P.: Analysis of Accidents in 2005 Fires in Portugal and Spain, Forest Ecology and Management, Vol. 234S, pp. 141, 2006.

[39] WEISENPACHER, P.: Forest Fire Simulation Capability of WFDS System, Proc. of the Int. Conf. on Natural Disaster Disturbed Areas, Strbske Pleso, pp. 227-237, 2007.

[40] WEISENPACHER, P.: Wildland-urban Interface Fire Simulation - WFDS system capabilities (in Slovak), Transactions of the VSB TU Ostrava, Vol. 3, Iss. 1, pp. 127-136, 2008.

[41] WEISENPACHER, P., GLASA, J., HALADA, L.: Computer Simulation of Fires in Automobile Engine Compartment, Proc. of the Int. Conf. on Fire Safety and Rescue Services, Zilina, pp. 78-87, 2010.

[42] WEISENPACHER, P., GLASA, J., HALADA, L.: Automobile Fires in Wildland-urban Interface, Proc. of the Int. Conf. on Forest Fire Research, Coimbra, 2010.

[43] WEISENPACHER, P., HALADA, L., GLASA, J., POLEDNAK, P., OKSA, G.: Experimental and Computational Study of Automobile Fires, Proc. of the Int. Conf. on Grid Computing for Complex Problems, Bratislava, 2010.

[44] XANTHOPOUlOS, G., VIEGAS, D. X., CABALLERO, D.: The Fatal Fire Entrapment of Artemida (Greece) 2007, In: Recent Forest Fire Related Accidents in Europe (VIEGAS, D. X., ed.), EC JRC, Luxembourg, pp. 65-75, 2009. 